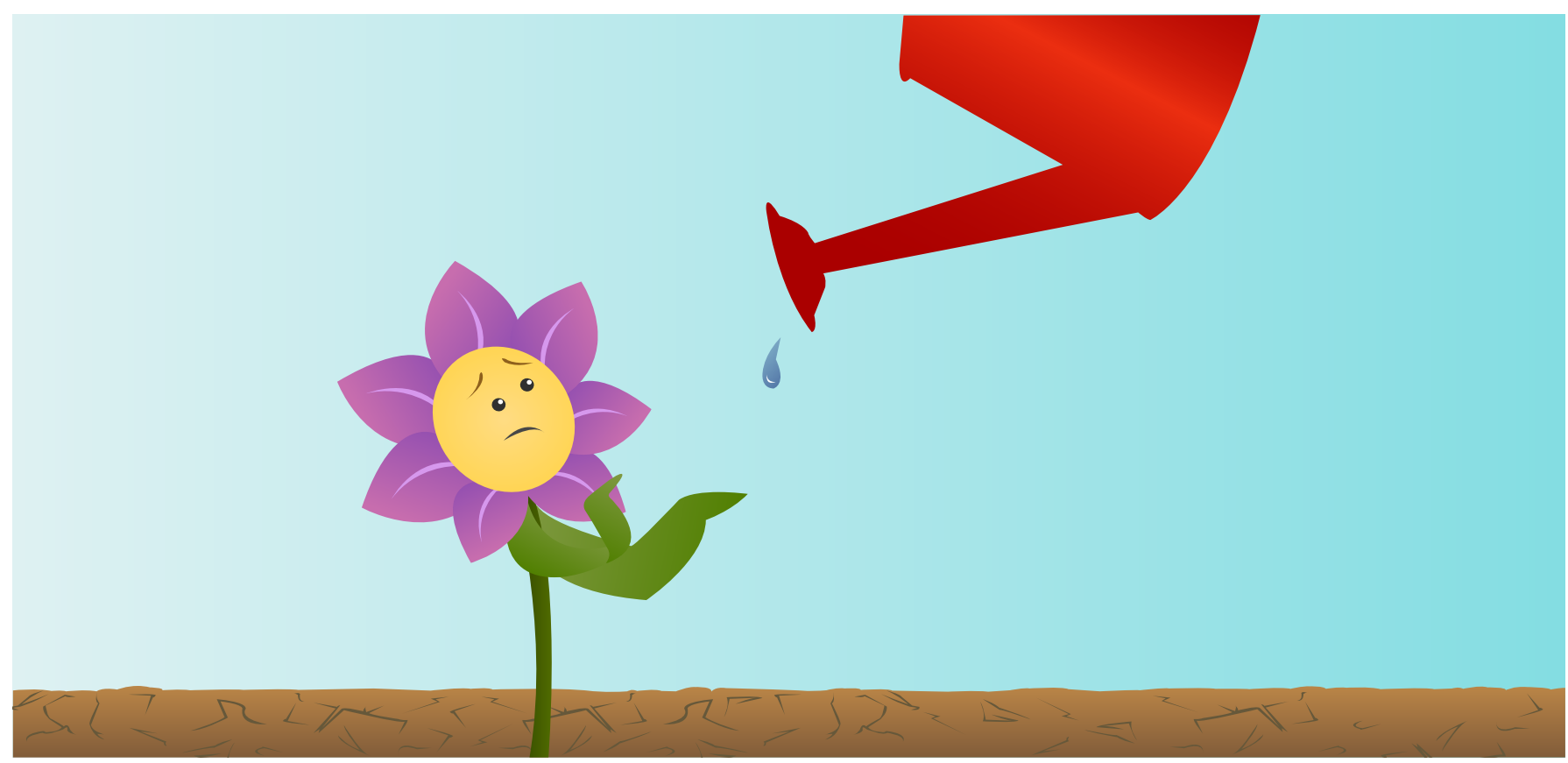

\title{
HOW DO PLANTS DEAL WITH DRY DAYS?
}

\section{Christell van der Vyver* and Shaun Peters}

Department of Genetics, Institute for Plant Biotechnology, Stellenbosch University, Stellenbosch, South Africa

\section{REVIEWED BY:}

HANA

10 YEARS OLD
Plants regularly face dry conditions. Not having enough water poses a serious threat to a plant's ability to grow and develop or even just survive! If plants die, we will not have enough food to eat! How do plants manage to survive during water shortages? They must somehow be able to sense, respond, and adapt to changes in water availability. They do this through a range of techniques that allow for a plant to combat water shortages. A plant's structural "armor" helps it to decrease the amount of water it loses to the environment and increase water storage. Plants respond to water shortages in very complex ways. These responses can include changes in the plants' growth and in their ability to protect themselves against toxic chemicals that accumulate in the plant during dry periods. All of a plant's responses are directly controlled by the plant's genes. If we can understand the genes that are involved in protecting plants against drought, in the future we might be able to make genetically modified crops that can tolerate global warming and climate changes.

Have you heard people speaking about global warming and climate change? Do you know what these terms mean? These terms basically imply that the earth is getting hotter every year. These higher temperatures lead to unexpected and unusual weather patterns. One of these extreme weather patterns is frequent and severe droughts. Droughts are very long dry periods without 


\section{SESSILE}

An organism that can't move and stays in one place, like a plant.

\section{SUCCULENTS}

Plants that have thickened and fleshy leaves and stems, in which water can be stored. any rain. What do severe droughts mean for plants? Well, plants are sessile, which means they stay in one place and can't move around like we can. They can't pull up their roots and relocate to a shady or damp spot. Therefore, plants somehow need to deal with these ever-increasing drought conditions, or they will simply die. Remember, plants are our food. We eat plants raw or cooked (those vegetables your mom insists you eat!) or processed, like your favorite box of breakfast cereal [which is made from wheat or maize (corn)]. So, if plants die because of droughts, we will not have enough food to eat!

If there is no water around, what can plants do to survive? Amazingly, all plants seem to have a number of genes for drought-defense strategies encoded in their DNA. Genes are small sections of DNA, like chapters in a book. How they use these genes determines their ability to survive drought.

Some plants are drought-resistant. When we talk about drought-resistant plants, we mean plants that can withstand dry conditions without dying. A drought-resistant plant can survive drought by using three defense strategies: escaping, avoiding or tolerating the loss of water [1]. Drought tolerant plants are quite rare in nature and can endure long periods with no water at all. Some of the most spectacular drought tolerant plants are called resurrection plants. Resurrection plants are able to survive long periods (up to 3 years!) without any water. However, give them a little water and they will spring back to life in a day or two. Other drought-resistant plants may not be as spectacular, but they too can survive short periods of drought using special techniques and defense strategies.

\section{SOME PLANTS HAVE SPECIAL STRUCTURES THAT HELP THEM TO SURVIVE IN DROUGHT CONDITIONS}

Some plants are able to survive droughts because of their unique structures. These structural features include the external armor of plants that protects them against water loss, as well as tools to help the plants absorb and store water. Drought-resistant plants can be specially adapted to live and survive in very dry environments. These plants often look quite different from plants living in areas where water is easily available. The drought-resistant plants normally have special "avoidance" (one of the defense adaptations!) features to make sure less water is lost to the environment or that more water gets absorbed and stored in the plant. Plants called desert succulents are a good example of plants that have drought avoidance strategies [2]. Desert succulents have thick fleshy leaves, which often don't resemble leaves at all, and they have a thick waxy layer to prevent water loss. Desert succulents also have extensive root systems that search for water under the dry desert soil (Figure 1). Some succulents have specialized roots that form large bulb structures, which are actually underground water reservoirs for the plant. These plants can survive years of drought using the water stored in their bulbs. 


\section{FIGURE 1}

Extreme structural adaptations found in plants to combat water loss and store more water.

\section{TRANSPIRATION}

The process where plant roots will take up water and then release water vapor through pores (stomata) in the leaves.

\section{STOMATA}

Little holes in the lower surface of a leaf through which water and gas can move in and out of a plant.

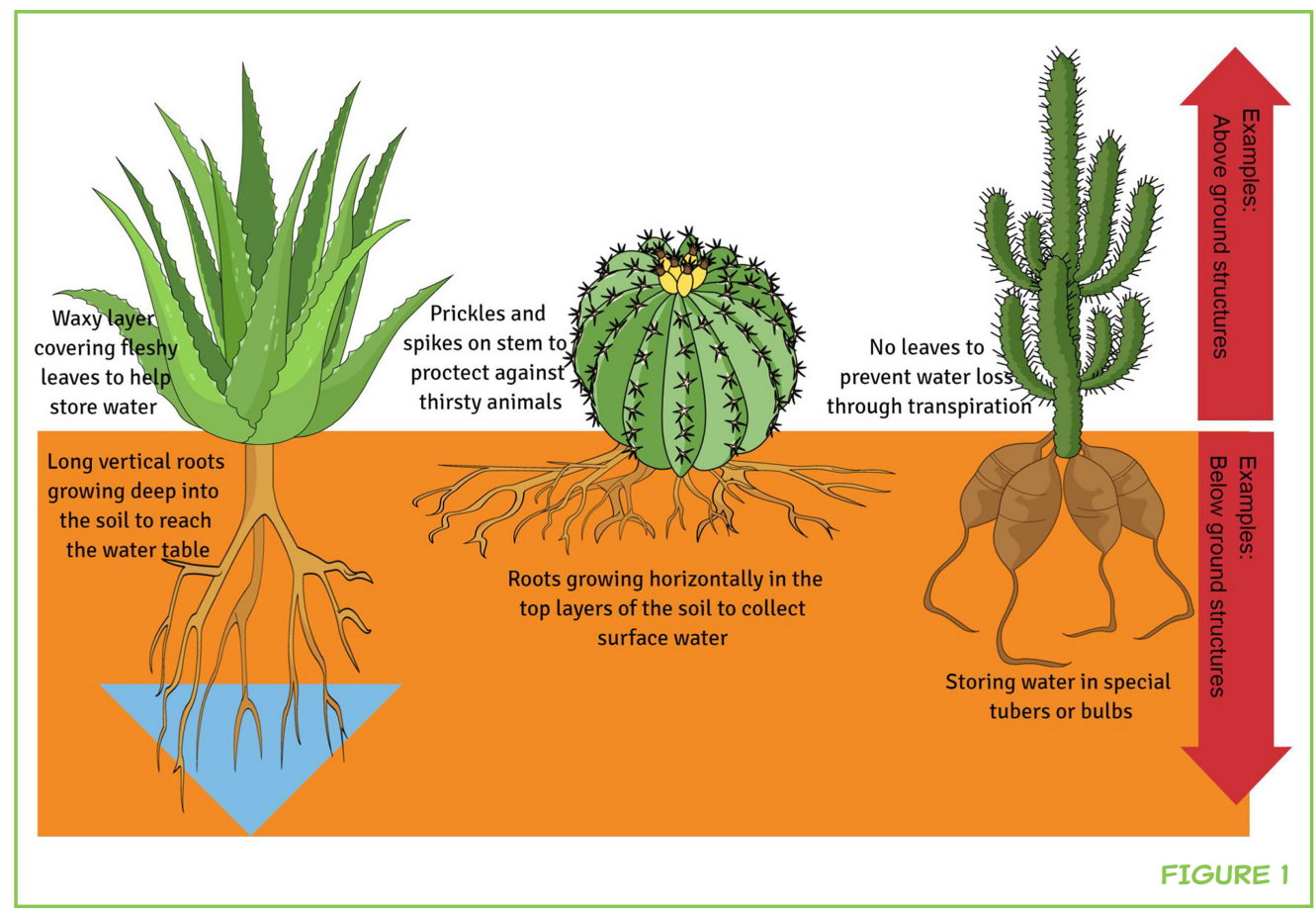

Most of the water a plant loses is lost due to a natural process called transpiration. Plants have little pores (holes or openings) on the underside of their leaves, called stomata. Plants will absorb water through their roots and release water as vapor into the air through these stomata. To survive in drought conditions, plants need to decrease transpiration to limit their water loss. Some plants that live in dry conditions have evolved to have smaller leaves and therefore fewer stomata. Extreme examples are plants with leaves that resemble spiky thorns. Some plants may also completely shed their leaves in a drought, to prevent water loss. The basic rule is that fewer leaves mean less water loss through transpiration. These extreme leaf adaptations can also protect the plants from hungry and thirsty birds and animals (Figure 1). You certainly would not like to have a prickly meal!

Some adaptations are quite clever and involve plants "escaping" drought as seeds (remember, escape is another defense strategy). The seeds survive during the dry spells and very quickly germinate (sprout), grow and produce more seeds when rains fall. These seeds are then scattered and can also survive extreme harsh conditions for long periods of time. Looking closely at desert soils, you will find a lot of seeds lying around, just waiting for rain before germinating again.

\section{SOME PLANTS ALSO HAVE INTERNAL DEFENSES AGAINST DROUGHT}

In addition to special structures, plants have internal defenses to protect them against water shortage, as well. When a plant experiences drought conditions, 
PHOTOSYNTHESIS

The process where plants use water, light and $\mathrm{CO}_{2}$ to produce their own food (in the form of sugars) and release oxygen into the air.

FREE RADICALS

Molecules that will react with, and damage, anything they come in contact with.

\section{ABA}

A plant hormone called abscisic acid that helps take care of the water balance in plants.

\section{TURGOR}

\section{PRESSURE}

The tension exerted on a plant cell wall by the fluids inside the cell. Imagine filling a balloon you've placed inside a glass jar. As you fill the balloon more, it presses up against the rigid glass jar just like the fluids against the rigid plant cell wall. some reactions will quickly happen inside the plant to help the plant with the stress of the drought. These reactions that occur in the plant are often quite complex and sophisticated. We will give you some examples.

\section{PLANTS STILL NEED TO PERFORM PHOTOSYNTHESIS DURING DROUGHT}

Plants are green because they contain a green chemical called chlorophyll. Chlorophyll is packed into special structures called chloroplasts, which are the energy factories of plants. Together with water and carbon dioxide $\left(\mathrm{CO}_{2}\right)$, chlorophyll uses sunlight to create sugars. These sugars allow the plant to grow and flourish. This is the process of photosynthesis and it is linked to the availability of water.

When there is not a lot of water in the plant's soil, the process of photosynthesis will happen a little differently and will result in the build-up of damaging chemicals called free radicals. This means that plants need to carefully control how they use the energy of the sun. During photosynthesis, $\mathrm{CO}_{2}$ must enter the plant through its stomata (the little pores mentioned earlier). But remember, open stomata mean that water will be lost through transpiration! So, the plant is faced with the difficult problem of making sure it has enough water and also enough $\mathrm{CO}_{2}$ for photosynthesis to occur. To do this, plants use a "manager" called abscisic acid (ABA).

When a plant experiences a shortage of water, $\mathrm{ABA}$ is rapidly produced and transported to the stomata. In the stomata, ABA controls how the stomata open and close by manipulating something called turgor pressure (Figure 2) [3]. Turgor pressure is the pressure applied on the wall of the plant cell by the fluids inside the cell. The more water is in the cell (the fuller the cell) and the bigger the pressure. Management of turgor pressure provides a balance between $\mathrm{CO}_{2}$ intake and water loss, so that photosynthesis can occur. But, if water remains limited in drought conditions, eventually the plant will be unable to cope with the stress of the drought and the entire photosynthetic process can stop working properly. However, drought-resistant plants have figured out a clever way to avoid the problem of losing water during photosynthesis. They only open their stomata during the cool of the night to take up $\mathrm{CO}_{2}$. They then store this $\mathrm{CO}_{2}$ and use it in the daytime for photosynthesis. This way, they lose less water during the day because they can keep the stomata closed, but they can continue to grow-although a little slower than normal.

\section{PLANTS NEED TO PROTECT THEMSELVES FROM DANGEROUS FREE RADICALS}

In drought conditions when a plant cannot seem to balance photosynthesis and water loss properly, the plant will have to deal with nasty little molecules 


\section{FIGURE 2}

Internal defenses of plants under water stress.

(A). When plenty of water is available in the soil, plants will absorb water through its roots. This water will be used by the plant or released through transpiration by open stomata in the leaves.

Photosynthesis will also occur normally with $\mathrm{CO}_{2}$ and oxygen being absorbed and released through the open stomata. (B). But when limited water is available in the soil, plants try to prevent water loss. Water loss through transpiration can be reduced by closing the stomata in the leaves using a substance called ABA. When the stomata is closed photosynthesis will decrease because no $\mathrm{CO}_{2}$ can enter through the closed stomata. Less photosynthesis means less energy is produced by the plant and the plant stops growing.

\section{OSMOSIS}

Moving water through a cell membrane from one cell to the next cell. Why? To ensure equal concentrations of solutes on both sides of the membrane.
A

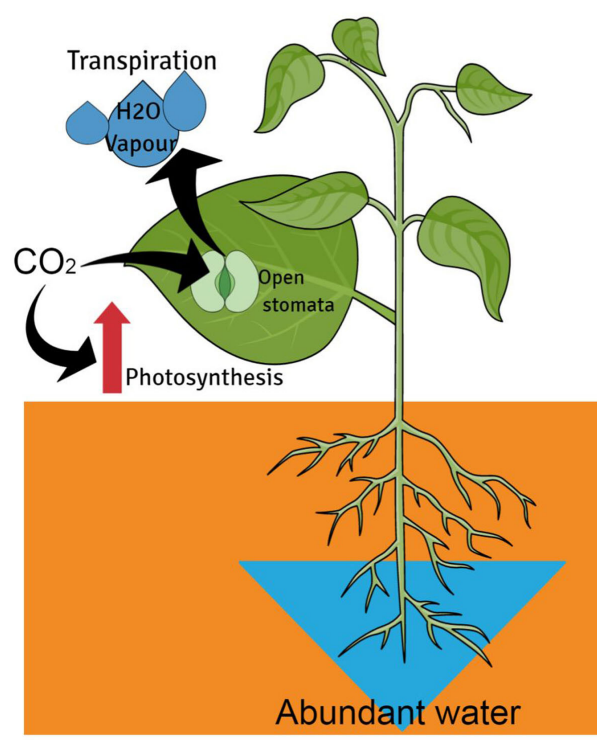

B Wilted plant

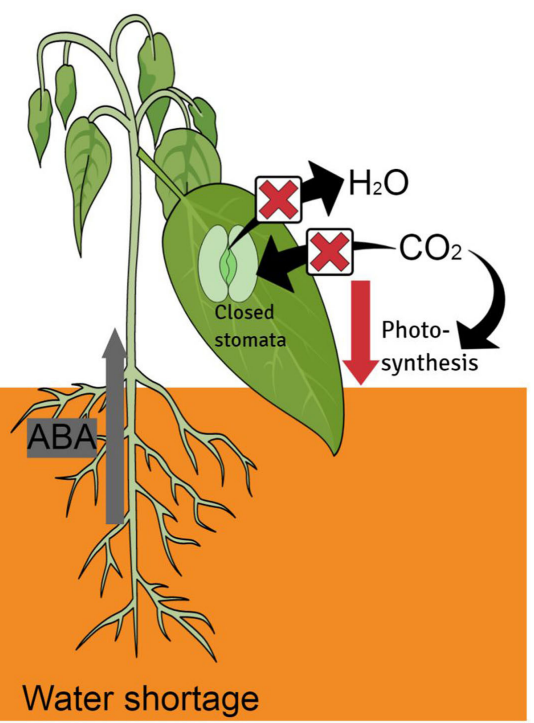

FIGURE 2

called free radicals. Free radicals occur naturally during photosynthesis, but when there isn't a lot of water available more free radicals form. Free radicals can be very dangerous for the cell, because they can cause damage to DNA, cell membranes, proteins, and sugars (all of these substances are essential for a cell's survival)!

Plants are used to dealing with low amounts of free radicals. However, drought tolerant plants are really good at dealing with free radicals, because they accumulate protective substances. These protective substances are called free radical scavengers. The presence of free radical scavengers often causes a change in the color of the plant. Plants often turn red or purple when these scavengers accumulate (do you see the purple leaves of the dry plant in Figure 3B?). The free radical scavengers occur widely in nature and are very good at mopping up free radicals to protect plants from their harmful effects.

\section{PLANTS NEED TO CONTROL THE AMOUNT OF WATER WITHIN THEIR CELLS}

Osmosis is an important concept in biology. Basically, osmosis is the movement of water across a membrane (like a cell membrane) to an area where certain molecules (like salts, sugars, and free radicals) occur in higher concentrations. By doing so, the water will dilute the concentration of these molecules so that the concentration is equal on both sides of the membrane. Now think about what happens to a plant that is suffering from the loss of water. There is not enough water to allow osmosis to occur, so molecules become super concentrated inside the plant cells. This is generally not a good thing, especially if these molecules are free radicals. 


\section{FIGURE 3}

The resurrection plant, Craterostigma pumilum. (A). This is how the plant looks when it is growing in conditions where enough water is available. (B). The two middle pictures show the plant when no water is available, after 3 weeks without water. Doesn't it look dead to you? (C). If the same dry, deadlooking plant is watered, within 2 weeks the plant will recover from the drought and start producing seeds.

\section{OSMOTIC}

ADJUSTMENT

Changing the concentration of solutes in a plant cell.

\section{SOLUTE}

The substance (like sugar) you are dissolving in a solution (like water).

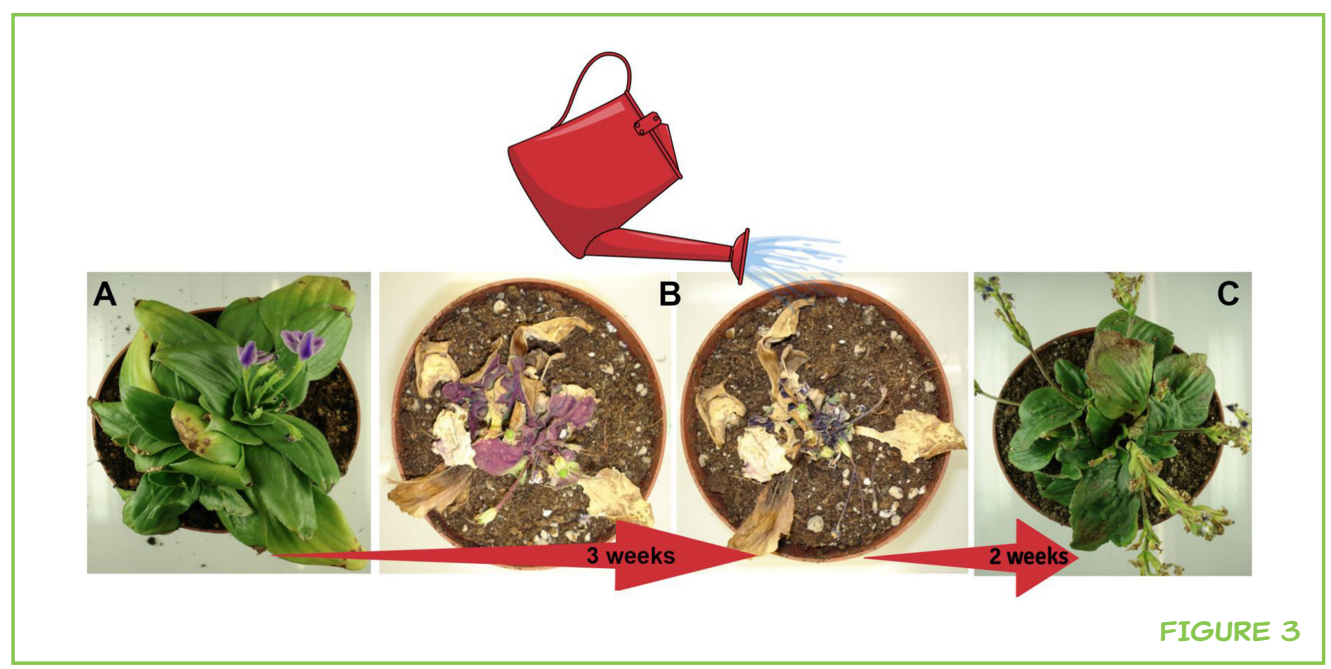

Once again, drought tolerant plants have some very cool strategies to fight this problem. At the first signs of drought, the cells of these plants will accumulate a bunch of molecules involved in what is called osmotic adjustment (OA) [3]. OA is the change is solute concentration in a cell. This is like when you dissolve sugar in water, where sugar is the solute. These molecules (solutes) can be sugars, amino acids or small proteins. The purpose of these molecules is to limit the movement of water out of the cell. What makes these OA molecules unique in drought tolerance is that they serve many functions. The OA molecules can physically bind to DNA and proteins to protect them from free radicals. They can also bind water itself, preventing it from moving out of the plant cells. These OA molecules also bind to membranes, stabilizing the structure of the plant when water is restricted.

Resurrection plants are perfect examples of how drought tolerant plants bring together the concepts we've discussed so far. Resurrection plants are able to survive complete loss of water. They accumulate vast quantities of OAs, release free radical scavengers and produce special protective proteins to survive long and severe droughts. They do all of this while they also fold their leaves away and wait until rain falls (Figure 3). The process can be compared to bears going into hibernation.

\section{A PLANT'S GENES CONTROL ITS RESPONSES TO DROUGHT}

Keep in mind that we have discussed these processes used to protect plants from drought in a very simplified manner. Looking closely at these processes is actually very complicated. At the very basic level, these processes are regulated by the plant's use of its genetic code-its genes. Substances necessary to survive drought will be produced by accessing this code at the right time. This accessing of the genetic code to help a plant survive a drought is called the genetic response of the plant. 
The genetic responses of a plant experiencing the stress of a drought are very complex-lots of genes are switched on or off. Using advanced computer technologies, scientists are now able to identify most of the genes that play a role in protecting a plant from drought. This technology has found that literally hundreds of genes are switched on and off, depending on where and when they are needed! We can't list all of these genes, because you will be completely bored at the end of the first page! What we will say is that these genes fall mainly into three groups: (1) genes that control other genes important for switching genes on and off; (2) genes that produce substances that help with drought protection in the plant; and (3) genes involved in water uptake and transport.

Why do you think it might be important to know which genes play a role in helping plants avoid or tolerate drought? Most of our crops are actually not able to survive droughts. How are we going to protect our crops or make them more resistant to these droughts? We need to use the knowledge of the genes that are turned on or off during drought conditions to produce plants that are more resistant to drought.

Over the years, plant scientists have had some success in producing droughtresistant crops. These drought-resistant crops were produced mainly by selecting and breeding individual plants that survived well under drought conditions. Over the past few decades, scientists working on genetically modified (GM) plants also started to focus on producing drought-resistant crops [4].

To produce a GM plant, a new gene (from any source!) is inserted into the DNA of the plant. By inserting this new gene/s, the scientist hopes to introduce a new, useful trait into the GM plant. Imagine being able to choose from hundreds of helpful genes in a resurrection plant and introduce some of them into wheat! Unfortunately, only a handful of GM drought-resistant plants (such as maize/corn and sugarcane) have been successfully produced. Much more work needs to be done, including convincing the general public that GM plants are not dangerous!

\section{CONCLUSION}

Plants are really vulnerable when it comes to water scarcity. Drought will influence a plant's growth, development, productivity and ultimately its survival. However, plants do have some built-in protection against drought. They can have some structural adaptations to avoid or tolerate dehydration. They also have some internal defenses that are activated to try to limit water loss when they realize water is becoming scarce. All of these defense systems are regulated by the plant's genes. Knowledge of these genes and how they are involved in protecting the plant against drought provide humankind with a hope to make drought-resistant GM crops. 


\section{ACKNOWLEDGMENTS}

Figures were created in the Mind the Graph platform (www.mindthegraph. com).

\section{REFERENCES}

1. Basu, S., Ramegowda, V., Kumar, A., and Pereira, A. 2016. Plant adaptation to drought stress. F1000Res 5(F1000 Faculty Rev):1554. doi:10.12688/ f1000research.7678.1

2. Dimmitt, M. A. 1997. How plants cope with the desert climate. Sonorensis. Vol. 17. Available at: http://www.desertmuseum.org/programs/succulents_adaptation.php

3. Osakabe, Y., Osakabe, K., Shinozaki, K., and Lam-Son, T. 2014. Response of plants to water stress. Front. Plant Sci. 5(86):1-8. doi:10.3389/fpls.2014.00086

4. Blum, A. 2014. Genomics for drought resistance - getting down to earth. Funct. Plant Biol. 41:1191-8. doi:10.1071/FP14018

SUBMITTED: 20 April 2017; ACCEPTED: 29 September 2017;

PUBLISHED ONLINE: 23 October 2017.

EDITED BY: Chelsea D. Specht, Cornell University, United States

CITATION: van der Vyver C and Peters S (2017) How Do Plants Deal with Dry Days? Front. Young Minds 5:58. doi:10.3389/frym.2017.00058

CONFLICT OF INTEREST STATEMENT: The authors declare that the research was conducted in the absence of any commercial or financial relationships that could be construed as a potential conflict of interest.

COPYRIGHT @ 2017 van der Vyver and Peters. This is an open-access article distributed under the terms of the Creative Commons Attribution License (CC BY). The use, distribution or reproduction in other forums is permitted, provided the original author(s) or licensor are credited and that the original publication in this journal is cited, in accordance with accepted academic practice. No use, distribution or reproduction is permitted which does not comply with these terms.

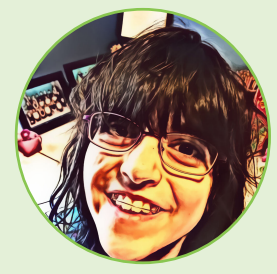

\section{REVIEWED BY}

\section{HANA, 10 YEARS OLD}

My name is Hana and I am just finishing 4th grade. My favorite subjects in school are culture and math. Outside of school, I like to read, do gymnastics, make crafts, and fold origami. I also like to travel with my parents. We have been to scientific meetings on two continents. This is my first Frontiers for Young Minds review and I really liked it. I plan to do more reviews. 


\section{AUTHORS}

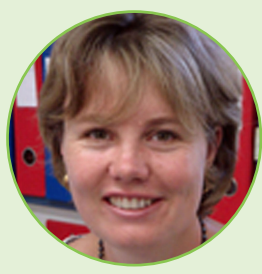

\section{CHRISTELL VAN DER VYVER}

My original university training was as a botanist. I even worked for years at a nursery over weekends! When I started to specialize at postgraduate level, I became interested in modern techniques that were rapidly evolving in the field of plant biology. It became possible to not only focus on how a plant looks or functions but also how a plant is genetically built. As a plant biotechnologist I use modern molecular techniques and tools to understand, improve and use plants to benefit people. I work mainly on sugarcane to study genes involved in stress and carbohydrate metabolism. ${ }^{*} \mathrm{Cvdv@sun.ac.za}$

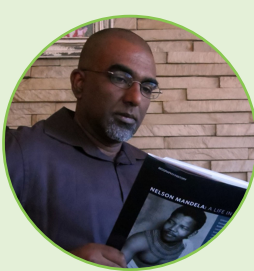

\section{SHAUN PETERS}

I have been fascinated by natural history since childhood and Sir David Attenborough has remained an inspirational figure throughout my life. My university studies led me to look at biological questions and unravel how things work at the molecular level. My main interest are sugars and how they are made and used by plants but, I have worked on quite a few interesting plants in my career that show tolerance to drought (like the resurrection plants in this article!). I enjoy communicating my passion for science and am infamous for using natural history examples when teaching university students. 